Web Jurnal:

http://ejournal.kemenperin.go.id/jli

Kementerian

Perındustrian

REPUBLIK INDONESIA
Jurnal Litbang Industri

| p-ISSN: 2252-3367 | e-ISSN: 2502-5007 |

\title{
Pengaruh jenis pelarut dan kecepatan homogenizer terhadap karakteristik partikel katekin gambir
}

\section{Effect of solvent type and homogenizer speed on particle characteristics of gambier catechins}

\author{
Gustri Yeni*, S Silfia, Yulia Helmi Diza \\ Balai Riset dan Standardisasi Industri Padang \\ J1. Raya LIK No. 23 Ulu Gadut Padang 25164, Indonesia \\ * e-mail: gustry@gmail.com
}

\begin{tabular}{l}
\hline INFO ARTIKEL \\
\hline Sejarah artikel: \\
Diterima: \\
17 Mei 2019 \\
Direvisi: \\
13 Juni 2019 \\
Diterbitkan: \\
28 Juni 2019 \\
\hline
\end{tabular}

\section{Kata kunci:}

ekstrak gambir;

ukuran partikel;

katekin

\begin{abstract}
ABSTRAK
Penelitian ini bertujuan untuk mengetahui pengaruh jenis pelarut dan kecepatan homogenizer terhadap karakteristik partikel katekin gambir. Penelitian dilakukan dengan cara katekin gambir dilarutkan dengan variasi pelarut air, etanol 20\%, campuran etanol $20 \%$ dan etil asetat (perbandingan 1:10) dan kecepatan homogenizer 500; 1.500; 2.000; dan $2.500 \mathrm{rpm}$. Karakteristik partikel hasil perlakuan diuji menggunakan particle size analyzer (PSA) diperoleh hasil bervariasi antara 2.148-3.354 nm. Proses pengadukan dengan kecepatan 2500 rpm dapat memperkecil ukuran partikel $(2.148 \mathrm{~nm})$, secara visual dilihat dari tingkat kejernihan larutan yang dihasilkan. Peningkatan kecepatan homogenizer menyebabkan terjadi kerusakan senyawa katekin yang ditandai dengan perubahan warna menjadi coklat, ditunjukkan dengan penurunan kadar katekin dari $84,32 \%$ menjadi $75,91 \%$. Sampel hasil perlakuan dikeringkan dengan spray dryer pada kondisi operasi suhu inlet $100^{\circ} \mathrm{C}$ dan outlet $90^{\circ} \mathrm{C}$, tekanan vakum pada 15 Psi, terjadi penurunan ukuran partikel $(209.45 \mathrm{~nm})$. Sampel diuji menggunakan scanning electron microscope (SEM) menunjukkan morfologi katekin tidak simetris. Analisis ukuran partikel katekin dilanjutkan menggunakan software image-J dan diperoleh ukuran partikel antara $209.53-280.50 \mathrm{~nm}$.
\end{abstract}

Keywords:

gambier extract; particle size; catechin

\begin{abstract}
This study was aimed to determine the effect of solvent type and homogenizer speed on the particle characteristics of gambier catechins. The research was conducted by dissolving the gambir catechins with solvents variation of water, ethanol 20\%, mixture of ethanol 20\% and ethyl acetate (ratio 1:10) and homogenizer speed 500; 1,500; 2,000; and 2,500 rpm. The particle characteristics of the treatment were tested using a particle size analyzer (PSA) and obtained the results varied between 2,148-3,354 nm. The stirring process at a speed of $2500 \mathrm{rpm}$ can reduce the particle size $(2,148 \mathrm{~nm})$, visually seen from the clarity level of the solution produced. Increasing the speed of the homogenizer caused damage to the catechin compound which was marked by a change in color became brown, indicated by a decrease in catechin content from $84.32 \%$ to $75.91 \%$. The treated sample was dried with a spray dryer under operating conditions of inlet temperature $100^{\circ} \mathrm{C}$ and outlet temperature $90^{\circ} \mathrm{C}$, vacuum pressure at 15 Psi particle size decreased (209.45 $\mathrm{nm}$ ). Samples were tested using a scanning electron microscope (SEM) showed the symmetrical morphology of the catechins. The analysis of catechins particle size was continued using the image-J software and obtained the particle size between 209.53-280.50 $\mathrm{nm}$.
\end{abstract}




\section{Pendahuluan}

Gambir merupakan ekstrak tanaman Uncaria gambir Roxb. yang diperoleh dari hasil pengempaan daun dan ranting kecil tanaman gambir yang direbus. Filtrat dienapkan dan endapan dicetak untuk selanjutnya dikeringkan. Indonesia merupakan pengekspor terbesar komoditi gambir, terutama berasal dari Sumatera Barat $(80 \%)$ dan sisanya dari Sumatera Utara, Sumatera Selatan dan Aceh (Yeni et.al, 2014).

Masyarakat tradisional menggunakan gambir untuk campuran makanan sirih dan obat-obatan. Ekstrak gambir di industri digunakan untuk pengawet pangan, kosmetik, obat-obatan, pewarna dan penyamak kulit. Katekin kandungan utama dari gambir dalam industri kosmetik dibutuhkan karena sifat antioksidannya dan sebagai astringen. Namun saat ini belum tersedianya teknologi penyediaan katekin sesuai kebutuhan industri dalam negeri (Rauf et al., 2010; Anggraini et al., 2013; Yeni et.al, 2014).

Isolasi katekin untuk sediaan farmasi dan kosmetik menggunakan berbagai metoda perbandingan pelarut etanol dan air serta cara maserasi yang dilakukan (Damanik et al., 2014; Irianty, Citra R., Jimmy Posangi, 2014; Rahmawati et al., 2012). Aplikasi katekin dari gambir untuk bahan baku kosmetik telah dilakukan untuk pembuatan formula krim tabir surya dan formula anti jerawat (Agustin et al., 2013) dan sebagai sediaan obat kumur (Amos, 2009). Pembuatan konsentrat polifenol gambir untuk pengawet pangan dilakukan dengan cara pencucian dan teknik absorbsi dengan absorben silika dan amberlit (Muchtar et al., 2010).

Katekin biasanya disebut juga dengan asam catechoat dengan rumus kimia $\mathrm{C}_{15} \mathrm{H}_{14} \mathrm{O}_{6}$, tidak berwarna, dan dalam keadaan murni sedikit tidak larut dalam air dingin tetapi sangat larut dalam air panas, larut dalam alkohol dan etil asetat, hampir tidak larut dalam kloroform, benzen dan eter. Katekin merupakan senyawa polifenolik yang memiliki sifat tidak stabil jika disimpan terlalu lama, mudah teroksidasi oleh cahaya dan panas. Senyawa ini akan mudah terdegradasi jika berada pada $\mathrm{pH}$ lebih dari 6,5 dan merupakan senyawa yang sangat reaktif (Yeni et al., 2017).

Pembuatan partikel katekin ukuran nano dapat dilakukan diantaranya menggunakan metoda emulsifikasi. Ukuran partikel senyawa aktif kecil dari 100 nanometer, sifat partikelnya akan berubah. Semakin kecil ukuran partikel kelarutan makin meningkat sehingga sediaan dapat meningkatkan bioavailabilitas obat dalam tubuh. Nanokristal juga memungkinkan pengembangan formulasi sediaan. Ukuran partikel adalah faktor yang kritis seperti obat tetes mata, sediaan topikal, cairan infus dan obat suntik (Martien et al., 2012; Pathak and Thassu, 2009; Rahmawati et al., 2012; Yeni et al., 2014).

Teknologi nanopartikel saat ini banyak digunakan untuk berbagai aplikasi guna meningkatkan fungsi dari produk seperti halnya produk kosmetik yang mulai menerapkan nanopartikel di dalam produknya. Produk kosmetik yang menerapkan teknologi nano bertujuan untuk mendapatkan perlindungan UV yang lebih baik, lebih mudah masuk ke lapisan kulit, efek yang lebih tahan lama, meningkatkan warna dan kualitas akhir yang baik. Saat ini beberapa produsen skin care telah menggunakan nanopartikel untuk menghantarkan formula antiaging ke dalam kulit karena memiliki efektivitas yang lebih tinggi, efisien dan efek yang bertahan lebih lama.

Teknologi nano memiliki target untuk mengantarkan bahan aktif pada kosmetik dan obatan lebih tepat sasaran dengan efek samping yang sangat kecil. Oleh karena itu, pengembangan sediaan obat berukuran nano menggunakan teknik seperti miling, homogenizer kecepatan tinggi, spray drying, dan nanopresipitasi, terus dilakukan untuk membuat senyawa obat nanokristal. Penggunaan teknik homogenizer kecepatan tinggi memiliki keuntungan dibandingkan teknik milling yang dapat merusak bahan dan biaya lebih murah dibandingkan menggunakan spray drying (Pardeike et al., 2009).

Untuk meningkatkan fungsi kosmetik, perkembangan teknologi nano ikut berperan untuk menghasilkan kosmetik yang berdayaguna tinggi. Penerapan nanoteknologi sudah berkembang melalui inovasi bahan kosmetik dan sistem drug delivery. Disamping itu, penerapan nanopartikel pada farmasi dan kosmetik akan lebih baik apabila menggunakan bahan-bahan alam yang relatif tidak memiliki efek samping (Anggraini et al., 2011; Rahmi et al., 2013) .

Berdasarkan hal tersebut di atas, telah dilakukan penelitian pembuatan nano partikel katekin gambir dengan homogenizer tekanan tinggi. Penelitian ini bertujuan untuk mengetahui pengaruh jenis pelarut dan kecepatan homogenizer terhadap karakteristik partikel katekin gambir untuk mendapatkan partikel berukuran lebih kecil dan homogen.

Pembuatan partikel nanokatekin dari gambir pada penelitian ini menggunakan metoda high speed homogenization, dilanjutkan dengan pengeringan menggunakan alat spray dryer. Katekin dengan ukuran kecil (nano) diharapkan dapat dimanfaatkan sebagai sediaan bahan baku farmasi dan kosmetik. Produk yang dihasilkan dapat meningkatkan nilai tambah katekin dari gambir.

\section{Metode}

Bahan yang digunakan adalah gambir yang diambil lansung dari petani berupa pasta yang akan dicetak dan belum terpapar dengan sinar matahari. Bahan baku berasal dari sentra gambir Siguntur Kabupaten Pesisir Selatan. Alat yang digunakan adalah mesin penghancur, penyaring, pengayak dan mesin press, peralatan gelas, kain saring dan wadah plastik.

Peralatan proses berupa alat homogenizer berupa reaktor pressure product industries (PPI) dengan pengaturan kecepatan dan mini spray dryer merek Bucci B.260. Peralatan uji scanning electron microscopy (SEM) jenis JSM-5310LV dan peralatan uji distribusi partikel dengan particle size analyzer (PSA) jenis Vasco.

\subsection{Pelaksanaan penelitian 2.2.1. Pencucian gambir}

Pencucian gambir dilakukan berdasarkan metoda yang dilakukan oleh (Muchtar et al., 2015) sebagai 
berikut: gambir pasta ditambahkan air mendidih sampai semua bahan larut sempurna. Saring kotoran yang ada dengan menggunakan kain saring. Larutan diendapkan \pm 24 jam sampai terpisah cairan dan padatan gambir. Padatan dicuci dengan menggunakan air dingin sebanyak 3 kali.

Endapan gambir dipress untuk mengeluarkan air yang tersisa dengan menggunakan alat press. Endapan gambir yang terbentuk dikeringkan dalam ruang yang mempunyai kelembaban yang rendah. Gambir yang sudah kering dihaluskan dan diayak dengan ukuran 60 mesh.

\subsubsection{Homogenisasi katekin gambir}

Untuk mendapatkan ukuran partikel yang homogen dan ukuran lebih kecil dilakukan dengan cara sebagai berikut: tambahkan $700 \mathrm{ml}$ pelarut ke dalam wadah yang sudah berisi gambir sebanyak 70 gr (perbandingan 1:10) dan aduk merata. Variasi pelarut (A) A1 = air, A2 = etanol 20\%, A3 = campuran etanol 20\% dan etil asetat $20 \%$. Sampel perlakuan dimasukkan ke dalam alat homogenizer dan diaduk dengan variasi kecepatan (B), yaitu kecepatan B1= $500 \mathrm{rpm}, \mathrm{B} 21500 \mathrm{rpm}, \mathrm{B} 3=2000$ $\mathrm{rpm}$ dan B4= $2500 \mathrm{rpm}$. Sampel untuk setiap perlakuan, masing-masing perlakuan pengulangan 2 (dua) kali. Ukuran partikel dengan menggunakan peralatan particle size analyzer (PSA). Sebagai pembanding terhadap perlakuan digunakan sampel bahan baku (A0B0).

\subsubsection{Pengeringan dengan alat spray dryer}

Sampel yang sudah dihomogenkan, dikeringkan menggunakan peralatan spray dryer. Kondisi operasi spray dryer adalah suhu inlet pada $100^{\circ} \mathrm{C}$, suhu outlet $90^{\circ} \mathrm{C}$ dan tekanan vakum pada 15 Psi (Yeni et al., 2017).

\subsubsection{Karakateristik bahan baku dan produk partikel katekin gambir}

Analisis bahan baku gambir dilakukan berdasarkan standar mutu gambir SNI 01-3391-2000. Analisis ukuran partikel dan distribusi ukuran partikel yang dinyatakan dalam indeks polidispersitas (IP) menggunakan PSA dan karakterisisasi morfologi partikel katekin gambir menggunakan SEM. Bahan baku dan produk hasil proses dilakukan pengujian terhadap kadar katekin.

\subsubsection{Analisis ukuran partikel dengan menggunakan program image-J dari data hasil uji dengan SEM.}

Hasil uji SEM katekin gambir dianalisis dengan menggunakan software image-J untuk mengetahui ukuran partikel katekin gambir (Kurniawan et al., 2011; Rivano, 2014). Analisis mikrografi adalah sebagai berikut: instal perangkat Image-J dan persiapkan gambar (data SEM). Tahap mengatur skala gambar atau kalibrasi untuk memperjelas gambar, yaitu dengan cara klik procces $>$ find edge. Hasil dari find edges dipertajam dengan perintah process smooth. Automatic threshold yang berfungsi untuk memperjelas visualisasi gambar yang akan diukur. Klik process $>$ binary>make binary.
Selanjutnya lakukan analisis gambar dengan cara klik analyze $>$ analyze particle. Data disajikan dalam bentuk excel. Untuk mencari diameter dapat digunakan rumus $\mathrm{d}$ $=2 \sqrt{ } \mathrm{A} / \pi \ldots .(1)$, dimana $\mathrm{d}=$ diameter; $\mathrm{A}=$ luas lingkaran ; $\pi=3,14$.

\section{Hasil dan pembahasan}

Berdasarkan hasil percobaan yang telah dilakukan, karakterisasi nanopartikel meliputi ukuran dan distribusi partikel, morfologi partikel, dan kandungan katekin.

\subsection{Analisis bahan baku gambir}

Spesifikasi bahan baku yang digunakan dalam penelitian adalah memiliki kadar air 74,84\%, kadar abu $1,8 \%$, kadar katekin (adbk) 67,99\%, bahan tak larut dalam air $10,58 \%$ dan kadar bahan tak larut dalam alkohol $13,33 \%$.

Hasil analisis menujukkan kadar air relatif tinggi melebihi standar maksimum mutu gambir yang disyaratkan karena gambir belum dikeringkan dan belum kena sinar matahari. Untuk parameter lainnya gambir yang digunakan memenuhi persyaratan standar mutu gambir SNI 01-3391-2000.

\subsection{Pengukuran distribusi dan ukuran partikel dengan metoda particle size analyzer (PSA)}

Pengukuran distribusi dan ukuran partikel merupakan salah satu bagian dari karakterisasi partikel katekin gambir. Ukuran partikel berpengaruh terhadap sifat dari partikel. Oleh sebab itu penentuan distribusi dan ukuran partikel dalam penelitian ini dilakukan untuk mengetahui perbedaan hasil dari variasi kecepatan pengadukan dan pelarut yang digunakan dengan alat homogenizer membentuk partikel yang lebih kecil.

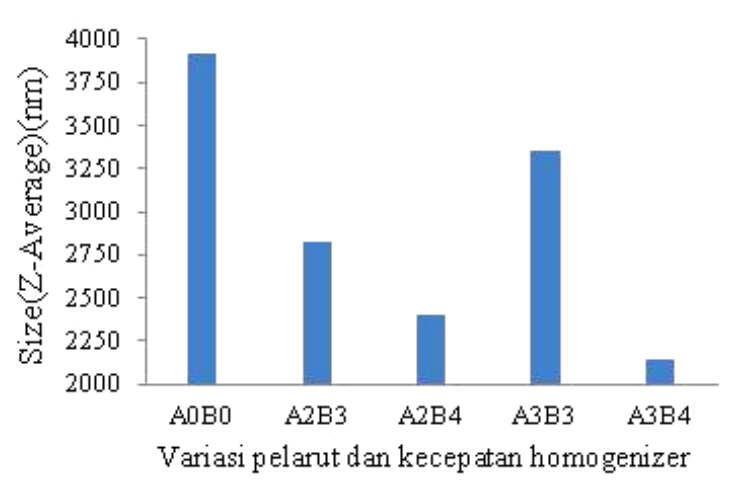

Gambar 1. Nilai rata-rata hubungan ukuran partikel variasi pelarut dan kecepatan pengadukan dengan homogenizer.

Pengaruh perlakuan variasi pelarut air (A1) dan Etanol (A2) dengan kecepatan pengadukan 500 rpm (B1) dan $1500 \mathrm{rpm}$ (B2) tidak dapat melarutkan katekin dengan baik. Produk hasil perlakuan tidak terlarut sempurna yang ditunjukkan dengan warna yang keruh dan terjadi pengendapan selama penyimpanan sehingga tidak dilakukan pengujian terhadap PSA dan SEM.

Pengujian ukuran partikel menggunakan PSA yang menyajikan data size (Z-Average) dan indeks 
polidispersitas (IP). Nilai IP merupakan ukuran dari distribusi massa molekul dalam sampel. Nilai IP dinyatakan sebagai berat rata-rata berat molekul dibagi dengan jumlah rata-rata berat molekul. Ukuran partikel mempengaruhi secara langsung terhadap keunikan sifat dari nanopartikel, sehingga penentuan ukuran dan distribusi ukuran nanopartikel harus dilakukan.

Hasil pengujian terhadap katekin hasil perlakuan diperoleh ukuran partikel katekin bervariasi antara 2.148-3.354 nm (Gambar 1). Partikel terkecil (2.148) diperoleh pada perlakuan A3B4, yaitu gambir yang dilarutkan dalam campuran etanol $20 \%$ dan etil asetat $20 \%$ yang dihomogenkan dengan kecepatan $2500 \mathrm{rpm}$. Ukuran partikel terbesar diperoleh dari pelakuan penambahan pelarut campuran etanol $20 \%$ dan etil asetat $20 \%$ dengan kecepatan homogenizer $2.000 \mathrm{rpm}$ (A3B3). Hal ini menunjukkan seluruh perlakuan ukuran partikel katekin masih berada di atas $1000 \mathrm{~nm}$ atau digolongkan sebagai mikro partikel. Kandungan katekin pada perlakuan ini, yaitu $75,91 \%$.

Berdasarkan Gambar 1 terlihat ukuran partikel hasil perlakuan lebih kecil dibandingkan dengan bahan baku (A0B0). Hal ini menunjukkan terjadi penurunan ukuran partikel akibat pengaruh pelarut yang digunakan dan kecepatan pengadukan.

Nilai IP menunjukkan keseragaman ukuran, makin kecil nilai mengindikasikan ukuran yang makin seragam. Untuk seluruh perlakuan dalam pembuatan nanopartikel katekin gambir diperoleh nilai IP berkisar antara 0,570,754 (Gambar 2). Nilai IP terkecil $(0,57)$ diperoleh pada perlakuan A2B3, yaitu menggunakan pelarut etanol yang diaduk pada kecepatan $2000 \mathrm{rpm}$. Data di atas menunjukkan bahwa semua perlakuan memiliki nilai IP besar dari 0,3 dan mengindikasikan ukuran patikel yang kurang seragam dan homogen.

Nilai IP lebih kecil dari 0,3 menunjukkan sampel memiliki distribusi ukuran nanopartikel yang semakin sempit dan ukuran diameter nanopartikel makin seragam atau homogen. Tetapi hampir tidak mungkin membuat partikel dengan ukuran seragam (monodispersi), walaupun didapatkan ukuran partikel monodispersi, tetapi sebenarnya adalah partikel polidispersi dengan sebaran ukuran partikelnya sangat sempit (Danhier et al., 2009).

Variasi kecepatan pengadukan dan pelarut diperoleh partikel yang mempunyai ukuran terkecil, yaitu pengadukan dengan kecepatan 2500 rpm, tetapi nilai IPnya masih besar. Nilai IP yang tinggi menunjukkan waktu dan kecepatan pengadukan yang diperpanjang belum menghasilkan penurunan ukuran partikel yang signifikan.

Hasil penelitian menunjukkan, kecepatan dan waktu pengadukan dapat mengurangi IP tetapi tidak signifikan mengurangi ukuran partikel (Gambar 2). Hubungan antara variasi pelarut dan kecepatan pengadukan dengan nilai IP untuk sampel sebelum dilakukan pengeringan dengan menggunakan spray dryer.

Keseragaman ukuran partikel (nilai IP) dipengaruhi oleh jenis pelarut yang digunakan. Pelarut etanol menghasilkan nilai IP paling rendah yang menunjukkan tingkat kelarutan dalam pelarut. Tingkat kelarutan juga menunjukkan jumlah komponen yang terdapat dalam sampel.

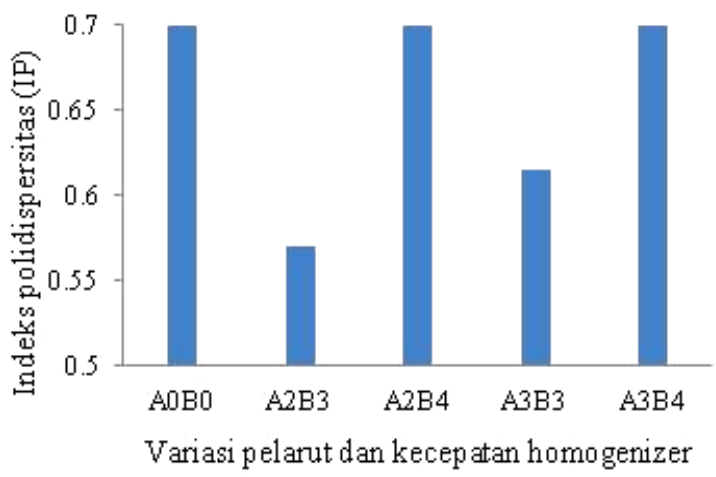

Gambar 2. Nilai rata-rata hubungan nilai IP dan variasi pelarut dan kecepatan pengadukan dengan homogenizer.

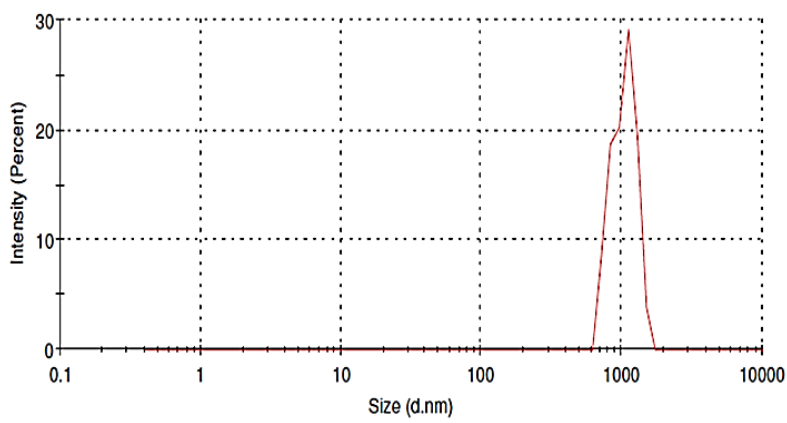

Gambar 3. Grafik hubungan ukuran partikel rata-rata $(\mathrm{nm})$ dengan intensitas (\%) pada sampel A2B3.

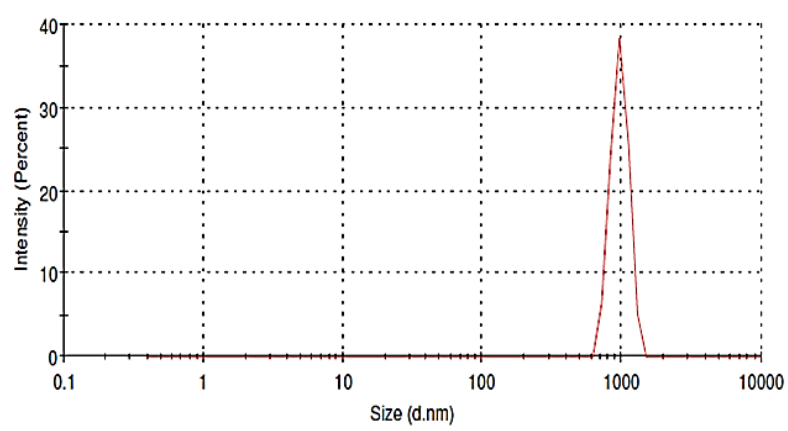

Gambar 4. Grafik hubungan ukuran diamater partikel rata-rata (nm) dengan intensitas (\%) pada sampel A2B4.

Nilai IP terkecil dari semua perlakuan (Gambar 3) menunjukkan puncak yang muncul pada puncak 3 dengan intensitas yang terbesar, yaitu 100, sedangkan puncak 2 dan 3 diperoleh 0 dengan nilai IP 0,57 dan merupakan nilai terkecil yang dihasilkan. Namun nilai IP masih di atas 0,3 yang mengindikasikan kurang seragam dan homogen. Penggunaan pelarut etanol (A2) dengan peningkatan kecepatan pengadukan dari $2000 \mathrm{rpm}$ (B3) menjadi $2500 \mathrm{rpm}$ (B4) meningkatkan nilai IP seperti terlihat pada Gambar 4. Hasil yang diperoleh adalah sebesar 0,754 merupakan nilai IP yang terbesar yang dihasilkan, mengindikasikan partikel katekin kurang 
seragam dan homogen. Lama dan kecepatan pengadukan berpengaruh terhadap mutu produk yang dihasilkan.

Hasil penelitian mengindikasikan proses pengadukan menggunakan high speed homogenizer dengan waktu proses yang lama dapat menurunkan ukuran partikel lebih kecil, dimana secara visual dilihat dari tingkat kejernian larutan yang dihasilkan, semakin jernih ukuran partikel makin kecil, tetapi waktu proses yang lama menyebabkan terjadi kerusakan senyawa dari katekin dengan penampakan fisik larutan berwarna semakin coklat.

\section{Tabel 1.}

Hasil analisis kadar katekin gambir variasi perlakuan hasil pengadukan dengan homogenizer kecepatan tinggi

\begin{tabular}{ll} 
Kode sampel & Kadar katekin gambir $(\%)$ \\
\hline A0B0 & 74,69 \\
A0B1 & 77,55 \\
A1B1 & 91,63 \\
A1B2 & 99,16 \\
A1B3 & 90,35 \\
A1B4 & 80,25 \\
A2B3 & 70,30 \\
A2B4 & 83,26 \\
A3B3 & 84,32 \\
A3B4 & 75,91 \\
\hline
\end{tabular}

Peningkatan kecepatan pengadukan dengan alat homogenizer akan menurunkan kadar katekin dari sampel (Tabel 1). Peningkatan kecepatan pengadukan menggunakan pelarut air (A1) dapat menurunkan kadar katekin partikel berturut-turut 99,16\%, 90,35\%, 80,25\%. Penurunan kadar katekin gambir dapat disebabkan karena terjadinya kerusakan bahan dalam proses, dimana selama proses terjadi panas yang dapat merusak bahan. Menurut (Yeni et al., 2017) bahwa katekin stabil pada suhu $>50 \pm 5^{\circ} \mathrm{C}$, suhu lebih tinggi menyebabkan terjadi kerusakan senyawa katekin dan menyebabkan terjadi perubahan dimana katekin berubah menjadi tanin.

\subsection{Morfologi nanopartikel}

Hasil foto SEM dengan pembesaran 2500 kali terhadap partikel katekin sebelum dilakukan pengolahan seperti diperlihatkan pada Gambar 5 dan sesudah pengolahan pada Gambar 6. Hasil foto SEM menunjukkan bahwa partikel katekin memiliki bentuk bola dengan permukaan yang kasar, mengkerut dan tidak simetris. Hal ini kemungkinan disebabkan rusaknya partikel katekin akibat hidrasi panas pada waktu pengeringan.

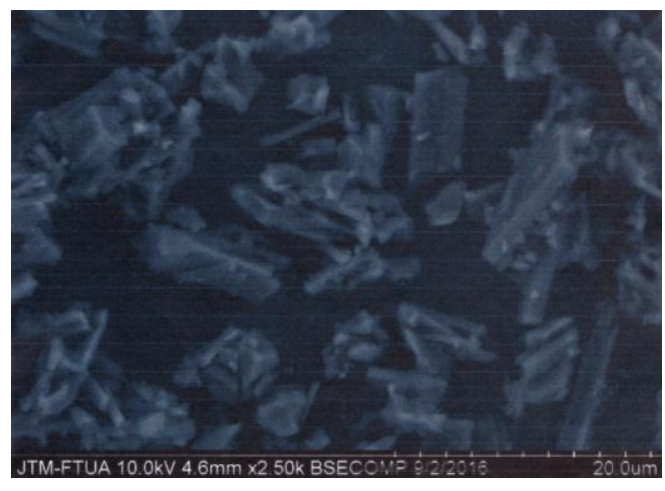

Gambar 5. Struktur partikel katekin hasil foto SEM dengan pembesaran 2500 kali sebelum dilakukan pengolahan.

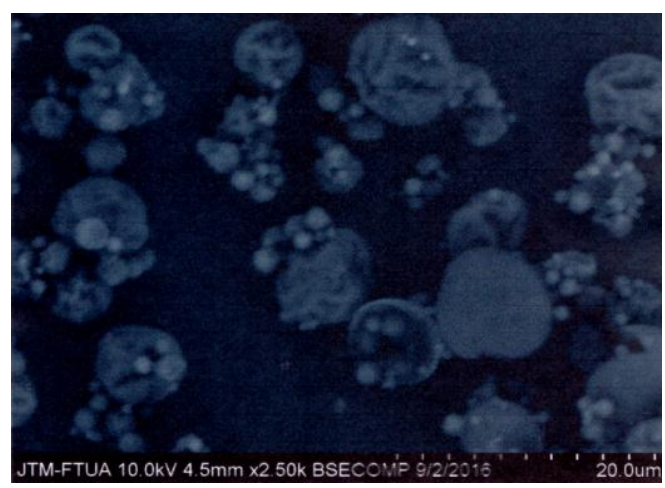

Gambar 6. Struktur partikel katekin hasil foto SEM sesudah diolah dengan pembesaran 2500 kali.

\subsection{Pengukuran partikel nanokatekin dengan menggunakan program image-J}

Data gambar analisis marfologi katekin dengan menggunakan SEM dilanjutkan analisis ukuran partikel katekin menggunakan program software image-j, diperoleh diameter ukuran, yaitu antara 209.4-280.5 nm dan ukuran diameter blanko adalah $871.0 \mathrm{~nm}$ (Gambar 7). Ketidakseragaman ukuran partikel juga terlihat dari hasil uji morfologi menggunakan SEM, dimana diperoleh ukuran partikel bervariasi dari yang sangat kecil hingga yang cukup besar.

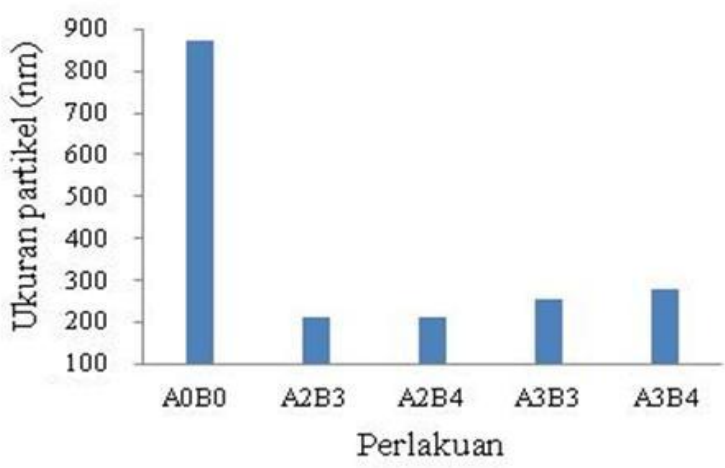

Gambar 7. Hubungan nilai ukuran partikel (nm) variasi pelarut dan kecepatan pengadukan dengan homogenizer. 
Data analisis diperoleh proses pengeringan katekin gambir menggunakan alat spray dryer dapat memperkecil ukuran diameter partikel katekin gambir yang cukup signifikan. Hal ini terlihat dari hasil perlakuan etanol $20 \%$ dan etil asetat $20 \%$ pengadukan $2500 \mathrm{rpm}$ (A3B4) dengan ukuran partikel $2.402 \mathrm{~nm}$. Setelah proses pengeringan dengan alat spray dryer ukuran partikel menjadi $209.45 \mathrm{~nm}$. Sampel hasil perlakuan pengunaan pelarut campuran dan pengadukan 2000 rpm (A3B3) sebelum dikeringkan diperoleh ukuran partikel katekin gambir sebesar $3.354 \mathrm{~nm}$ dan setelah dikeringkan dengan alat spray dryer menjadi $256.52 \mathrm{~nm}$.

Semua perlakuan penelitian diperoleh diameter ukuran partikel antara 209.4-280.5 nm. Kecendrungan saat ini untuk menyediakan bubuk yang lebih halus guna mendapatkan proses yang maksimum, semakin halus suatu partikel semakin besar pula luas permukaan yang dapat meningkatkan reaktifitas material (Muchtar et al., 2015).

\section{Kesimpulan}

Hasil penelitian dapat diambil kesimpulan bahwa jenis pelarut dan kecepatan homogenizer berpengaruh terhadap ukuran partikel $(\mathrm{nm})$ dan keseragaman partikel (IP). Kecepatan homogenizer dapat menurunkan ukuran partikel katekin. Ukuran partikel terkecil $(209.53 \mathrm{~nm})$ dengan IP terendah $(0,57)$ diperoleh pada perlakuan A2B3 (pelarut etanol 20\% dan kecepatan homogenizer $2000 \mathrm{rpm}$ ). Secara visual ukuran partikel dilihat dari tingkat kejernian larutan, semakin jernih larutan makin kecil ukuran partikel.

Hasil analisis marfologi partikel menggunakan SEM, kecepatan tinggi dan waktu yang lama menghasilkan bentuk morfologi yang tidak utuh atau keriput. Produk hasil pengeringan dikeringkan menggunakan spray dryer dan dianalisis dengan software image-J diperoleh ukuran diameter partikel antara 209.53-280.5 nm dengan blangko sebesar $871.04 \mathrm{~nm}$.

\section{Daftar pustaka}

Agustin, R., Oktadefitri, Y., Lucida, H., 2013. Formulasi krim tabir surya dari kombinasi etil p-metoksisinamat dengan katekin, in: Prosiding Seminar Nasional Perkembangan Terkini Sains Farmasi Dan Klinik III 2013. pp. 184-198.

Amos, 2009. Gambir sebagai antibakteri dalam formulasi obat kumur. J. Sain dan Teknol. 11, 188192.

Anggraini, D., Rahmawati, N., Hafsah, S., 2013. Formulasi gel anti jerawat dari ekstrak etil asetat Gambir. J. Penelit. Farm. Indones. 1, 62-66.

Anggraini, T., Tai, A., Yoshino, T., Itani, T., 2011. Antioxidative activity and catechin content of four kinds of Uncaria gambir extracts from West Sumatra, Indonesia. African J. Biochem. Res. 5, 33-38.

Damanik, D.D.P., Surbakti, N., Hasibuan, R., 2014. Ekstrak katekin dari daun gambir (Uncaria gambir Roxb) dengan metode maserasi. J. Tek. Kim. USU 3, 10-14. https://doi.org/10.1007/978-1-4419-0823-0
Danhier, F., Lecouturier, N., Vroman, B., Jérôme, C., Marchand-Brynaert, J., Feron, O., Préat, V., 2009. Paclitaxel-loaded PEGylated PLGA-based nanoparticles: In vitro and in vivo evaluation. J. Control. Release 133, 11-17. https://doi.org/10.1016/ .jconrel.2008.09.086

Irianty, Citra R., Jimmy Posangi, P.. W., 2014. Uji efek analgesik ekstrak etanol kelopak bunga matahari (Helianthus annus L) pada mencit swiss (Mus muculus). J. e-Biomedik 2, 1-6.

Kurniawan, C., Waluyo, T.B., Perdamean Sebayang, 2011. Analisis ukuran partikel menggunakan free software Image-J, Serpong., in: Seminar Nasional Fisika. pp. 1-9.

Martien, R., Adhyatmika, Irianto, iriamie d k, Farida, V., Sari, D.P., 2012. Technology developments nanoparticles as drug delivery systems. Maj. Farm. 8, 133-144.

Muchtar, H., Anova, I.T., Yeni, G., 2015. Pengaruh kecepatan pengadukan dan kehalusan gambir serta variasi komposisi terhadap beberapa sifat fisika dalam pembuatan tinta cetak. J. Litbang Ind. 5, 131. https://doi.org/10.24960/jli.v5i2.674.131-139

Muchtar, H., Yeni, G., Wilsa Hermianti, Diza, Y.H., 2010. Pembuatan konsentrat polifenol Gambir (Uncaria Hunter Roxb) sebaagai bahan antioksidan pangan. J. Ris. Ind. IV, 71-82.

Pardeike, J., Hommoss, A., Müller, R.H., 2009. Lipid nanoparticles (SLN, NLC) in cosmetic and pharmaceutical dermal products. Int. J. Pharm. 366, 170-184. https://doi.org/10.1016/j.ijpharm.2008.10. 003

Pathak, Y., Thassu, D., 2009. Drug delivery nanoparticles formulation and characterization, Drug Delivery Nanoparticles Formulation and Characterization. https://doi.org/10.3109/ 9781420078053.

Rahmawati, N., Bakhtiar, A., Putra, P., 2012. Isolasi katekin dari gambir (Uncaria gambir (Hunter) Roxb) untuk sediaan farmasi dan kosmetik. J. Penelit. Farm. Indones. 1, 6-10.

Rahmi, D., Yunilawati, R., Ratnawati, E., 2013. Pengaruh nano partikel terhaddap aktifitas antiageing pada krim. J. Sains Mater. Indones. 14, 235-238.

Rauf, R., Santoso, U., Suparmo, 2010. Aktivitas penangkapan radikal DPPH ekstrak Gambir (Uncaria gambir Roxb.) 30, 1-5. https://doi.org/10.22146/ agritech.9684.

Rivano, R., 2014. Aplikasi image-j untuk menghitung perubahan luas inti eritrosit bebek akibat larutan hipotonis rendi rifano.

Yeni, G., Syamsu, K., Mardliyati, E., Muchtar, H., 2017. Penentuan teknologi proses pembuatan Gambir murni dan katekin terstandar dari gambir asalan. J. Litbang Ind. 7, 1. https://doi.org/10.24960/jli.v7i1. 2846.1-10

Yeni, G., Syamsu, K., Suparno, O., Mardliyati, E., Muchtar, H., 2014. Repeated extraction process of raw gambiers (Uncaria gambier Robx.) for the catechin production as an antioxidant. Int. J. Appl. Eng. Res. 9, 24565-24578. 